DOI: $10.33067 /$ SE.4.2021.2

Agnieszka Legucka *

Agata Wtodkowska ${ }^{\star \star}$

\title{
The Eastern Partnership as a Contested Neighbourhood: The Role of External Actors - The EU and Russia
}

\begin{abstract}
Contestation remains a significant factor in the EU neighbourhood. The aim of this article is to elaborate on the role of external actors - namely the European Union and the Russian Federation - in managing local and regional contestation. The latter is defined as incompatibilities between two or more competing views about how political, economic, social, and territorial order should be established and/or sustained. Competing interests between the EU and Russia concern many issues; the model of political system in the neighbourhood (democracy vs. authoritarianism), the model and direction of the economic integration of these countries (European or Eurasia integration), and the infrastructure and availability of gas and oil (energy disputes). The common neighbourhood, which concerns EU Eastern Partnership (EaP) countries (Armenia, Azerbaijan, Belarus, Georgia, Moldova, and Ukraine), has become an area of rivalry rather than cooperation between the EU and Russia. The first seeks to stabilise the post-Soviet area, while Russia exploits local destabilisations and conflicts to maintain its influence there.
\end{abstract}

Keywords: Russia, European Union, Eastern Partnership, Rivalry, Clash of Interests

* Agnieszka Legucka - The Academy of Finance and Business Vistula in Warsaw, The Polish Institute of International Affairs (PISM), e-mail: a.legucka@vistula. edu.pl, ORCID: 0000-0002-9438-2606.

$\star \star$ Agata Włodkowska - The Academy of Finance and Business Vistula in Warsaw, e-mail: a.wlodkowska@vistula.edu.pl, ORCID: 0000-0002-7676-0693. 


\section{Introduction}

The common neighbourhood of the European Union and the Russian Federation covers a territory of over $1,031,114 \mathrm{~km}^{2}$, including the European countries of Ukraine $\left(603,628 \mathrm{~km}^{2}\right)$, Belarus $\left(207,600 \mathrm{~km}^{2}\right)$, and Moldova $\left(33,843 \mathrm{~km}^{2}\right)$ and the Caucasus countries of Georgia $\left(69,700 \mathrm{~km}^{2}\right)$, Armenia $\left(29,743 \mathrm{~km}^{2}\right)$ and Azerbaijan $\left(86,600 \mathrm{~km}^{2}\right)$. The European Union, through its enlargement in 2004 and 2007, has geographically approached an unstable region with political, economic, and security-based disturbances. In turn, these states are the so-called 'near abroad' for the Russian Federation, which is treated as a buffer zone that separates Russia from international challenges such as the expansion of hostile military-political alliances. Therefore, the region is a key element of the Russian Federation's security policy and a "zone of privileged interests of Russia". In the case of the region and Russian policy, the two concepts are not mutually exclusive. The ongoing rivalry over the $\mathrm{EaP}$ states means that, on the one hand, they are perceived by Russia as a zone of vital interests and as a buffer zone.

The European Union pursues a policy based on values and attraction, or so-called "soft" power. The Russian Federation, to a greater extent, uses "hard" power in the post-Soviet area and, by means of threats or payments, regulates relations between states using, among other things, "protracted conflicts" in the region. EU documents treat EaP countries as a group and adopt certain standards and mechanisms of cooperation. However, the capacity to promote resilience on the part of the EU is limited, while, on the other hand, the capacity for contestation on the part of Russia's part remains significant. This paper follows the conceptual framework of the EU-LISCTO project (Europe's External Action and the Dual Challenges of Limited Statehood and Contested Orders), ${ }^{1}$ which assumes that neighbouring countries suffer from a presence of areas of limited statehood and contested orders (CO). In addition, they are exposed to various domestic and external risks. This paper will concentrate on the $\mathrm{CO}$, and seeks to answer the following question: To what extent are the contested orders in the EaP countries fuelled by Russia, and how can the EU mitigate those risks?

At this point, it is worth making note of the EaP initiative itself, which was proposed in the summer of 2008 by Poland and Sweden, and approved by the European Commission in December of the same year. The inauguration of the Eastern Partnership took place in May 2009, during the Czech presidency. The EaP initiative is the enhanced cooperation of the EU Member States with their eastern neighbours and countries of South Caucasus

1 EU-LISCTO project has received funding from the European Union's Horizon 2020 research and innovation programme under grant agreement no. 769886. 
in bilateral and multilateral dimensions. It focuses, among other things, on stimulating cooperation between the EaP countries to build regional ties, strengthening democracy, including primarily strengthening internal stability, economic reforms and the removal of trade barriers, building free trade zones, environmental protection, and energy security. In this article, the term EaP refers to the above-mentioned countries, i.e., Belarus, Ukraine, Moldova, Armenia, Azerbaijan, and Georgia. In the text, next to the term EaP, we interchangeably use the term EaP countries, avoiding the name Eastern Europe. The latter also refers to Russia, which the authors treat as the second external actor in the region, along with the EU.

\section{Contested Order (CO) in the EU Neighbourhood}

According to Tanja A. Börzel and Thomas Risse, contested orders can be conceptualised as "incompatibilities between two or more competing views about how political, economic, social, and territorial order should be established and/or sustained". ${ }^{2}$ In the EaP, $\mathrm{CO}$ takes various forms, from minor societal and political splits, to violent conflicts or government breakdown. Orders can also be contested in situations where actors compete to establish their own sets of rules, e.g., the EU-Russian competition over region-building in the Eastern neighbourhood. Order contestations always involve competing ideas and discourses about what is considered an appropriate political, economic, or social system. ${ }^{3}$

The EU and the Russian Federation compete in the political, economic, and cultural domains, ${ }^{4}$ and both actors seek to limit the influence of the other. A goal declared by both the EU and Russia is the stabilisation of the situation in the Eastern Partnership. It should be emphasised, however, that both actors understand the concept of stabilisation differently. Stabilisation is often aimed at establishing a situation in line with one's interests, and this often manifests itself in supporting initiatives for conflict resolution, the implementation of which would allow for an increase one's influence in a given country or subregion. In the case of the Russian Federation, this also means weakening the states involved in the conflict or struggling with the problem of separatism. For being involved in the conflict indirectly or as a mediator, Russia firstly has an influence on the course of the conflict, secondly, on its freezing or unfreezing, thirdly, on the internal

2 A. Börzel, T. Risse, Conceptual framework: fostering resilience in areas of limited statehood and contested orders, "EU-LISTCO Working Paper", no. 1/2018, p. 18, DOI: https://doi.org/10.1093/oxfordhb/9780198797203.013.1.

${ }^{3}$ Ibidem.

4 A. Włodkowska-Bagan, Rywalizacja międzynarodowa na obszarze poradzieckim, Warszawa 2013. 
situation of the state in conflict, and, finally, on its foreign policy. The latter can be applied to blocking potential membership in NATO or the EU, where, among other things, issues of territorial integrity remain important. For the EU, the stabilisation of the situation in the countries in question currently involves mainly strengthening their political and economic systems internally, so that in times of crisis they are able to withstand pressure and remain stable. In previous years, the EU declared, without any tangible results, that it would increase its involvement in conflict resolution. The EU has not played the role of mediator in any of the conflicts in the EaP countries, though it has supported the normalisation of relations between the warring parties through EU member states participating in mediation, e.g., France and Germany, as part of the Normandy format with Ukraine and Russia, which is focused only on Donbass.

It is also in the interests of the $\mathrm{EU}$ and Russia to involve the EaP states in multilateral cooperation within their institutions or to create such institutions under their auspices. Often, these organisations are meant to counterbalance or contest the influence of a rival in the region or a structure in which it has a decisive voice and they may provide an alternative model of institutionalised cooperation that attracts competing states. Hence, it is also in the interest of individual powers to broaden the influence of their values and systemic models. In the case of Russia, it is both The Collective Security Treaty Organization, the Commonwealth of Independent States, and now primarily the Eurasian Union. For the EU, it is, among other things, an EaP initiative to bring these states closer to the EU, along with their democratisation, and the strengthening of their internal institutions and their economies. An important element of the EaP remains the rapprochement of societies between EaP states and the EU.

The contested order we are dealing with in the region indicates both the rivalry, as discussed above, and the order. The latter can be related to the rules that govern this rivalry and the continuity of involvement of external actors - Russia and the EU (and, earlier, the European Community). The dominant role in the region is played by Russia, which results from a number of advantages it holds over the EU. These include the vitality of its interests in the area, a structural unity facilitating decisionmaking and implementation, a better knowledge of the countries of the common neighbourhood, and a dependency system with the USSR. Also significant is Russia's greater propensity to use hard power, including the threat and use of force. On the one hand, it limits the policy of the EaP countries that is aimed at Russian interests, but on the other, the aggression against Ukraine in 2014 led to a sustained trend of strengthening EU influence in the country and a clear weakening of Russian influence. 
Making some generalisations, it can be said that the contradiction of EU and Russian interests in the common neighbourhood can be narrowed down to two issues; maintaining the status quo, and changing it. In the case of Russia, it will maintain its dominant role in the region. ${ }^{5}$ The EU, having interests located in the region, is currently striving to strengthen its presence only to a certain extent and is currently focusing more, as already mentioned, on supporting systemic reforms in the EaP countries to make them more resistant to Russian pressure. It can, therefore, be concluded that the EU's goal is to change the status quo, i.e., to strengthen the states of the region and thus undermine Russian domination.

\section{Russia's Contestation in EaP Countries}

Russia's most important means of contesting the order in EaP states include supporting separatism and simultaneously participating in mediation, promoting its political model as well as its military presence, and applying economic pressure. Russia is able to trigger spontaneous anti-Russian protests and local contestation while it supports pro-Russian regimes and specific politicians. Additionally, the Russian model of contesting order in neighbourhood countries involves using massive numbers of fake accounts, spreading false information, and undermining social trust.

The most effective tool of the Russian contestation of EaP countries is that of protracted conflicts. Five out of six EaP countries are affected by them (Belarus being the exception). They are defined as being prolonged and unresolvable disputes due to their nature and complexity. Definitions of this phenomenon are imprecise but must be seen from the perspective of the creation of de facto states that lack full international recognition and which are used by a stronger power in international relations. Such long-lasting conflicts in the eastern neighbourhood of the EU have been present in Transnistria, Abkhazia, South Ossetia, Nagorno-Karabakh, and currently in Donbas. They are sometimes referred to as "frozen conflicts", but this is a misleading term that does not reflect the political context of these disputes because the military clashes are, in fact, present from time to time, so they are not "frozen". ${ }^{6}$ The elements affecting the

${ }^{5}$ T.A. Börzel, V. Hüllen, One voice, one message, but conflicting goals: cohesiveness and consistency in the European Neighbourhood Policy, "Journal of European Public Policy", vol. 7(21)/2014, DOI: https://doi.org/10.1080/13501763.2014.912147.

6 T. de Waal, N. von Twickel, Beyond Frozen Conflict Scenarios for the Separatist Disputes of Eastern Europe, CEPS, Brussels 2020; A. Legucka, Frozen and Freezing Conflicts in Eastern Europe and South Caucasus: Implications for Regional Security, "Yearbook of the Institute of East-Central Europe”, no. 15, vol. 2/2017, pp. 79-97. 
complexity of these conflicts may be ethnic, political, and historical specificities, as well as the involvement of external actors which contribute to the escalation or prolongation of a dispute. ${ }^{7}$

Most of these conflicts actually escalated upon the fall of the USSR. The contemporary conflicts in the EaP states and the rest of the post-Soviet space are influenced by the border adjustments carried out in Soviet times or by the inclusion of culturally and religiously different areas into the various republics based on autonomy. In addition to the artificial drawing and redrawing of borders, the national policy of the USSR abounded in repressions and deportations, the aim of which was to change ethnic relations within a given area and to strengthen Russian influence in the other republics. As a result, there is a large Russian and Russian-speaking population in these states, which often serves as a pretext for Russian interference in the internal affairs of post-Soviet countries. The cultural differences that had been suppressed for decades and the old grudges that arose at the time of the collapse of the Soviet Union gave rise to armed clashes and separatist movements.

The consequence of most conflicts is the existence of quasi-states (not recognised by the international community, but with some attributes of statehood, including a parliament, president, and armed forces). We are dealing with this situation in Transnistria, Nagorno-Karabakh, as well as South Ossetia and Abkhazia. A common feature of all the abovementioned quasi-states is the stationing of Russian troops or Russian (possibly "multinational" with a clear preponderance of Russian forces) "peacekeepers" on their territories. ${ }^{8}$ Do note that while Transnistria and Nagorno-Karabakh have not been recognised as states by Russia, the rebellious Georgian provinces received Russian recognition in 2008. Within eastern Ukraine, separatists also established states in 2014 (Luhansk and the Donetsk People's Republic) that have not received international recognition, and that includes Russian recognition.

There is some misunderstanding about Russia's annexation of Crimea because some scholars call this a protracted conflict, too. ${ }^{9}$ But Crimea constitutes a highly special case. Since 2014, the peninsula has been de

7 P. Coleman, Characteristics of Protracted, Intractable Conflict: Toward the Development of a Metaframework-I. Peace and Conflict, "Journal of Peace Psychology", vol. 9(1)/2003, DOI: https://doi.org/10.1207/S15327949PAC0901_01.

8 A. Legucka, Operacja pokojowa Rosji w Górskim Karabachu - cele i wyzwania, „Biuletyn PISM”, no. 17(2215), 29.01.2021.

9 A. Racz, The frozen conflicts of the EU's Eastern neighbourhood and their impact on the respect of human rights, European Parliament, Directorate-General for External Policies, http://www.europarl.europa.eu/RegData/etudes/STUD/2016/578001/ EXPO_STU(2016)578001_EN.pdf(access 12.10.2021). 
facto controlled by and within the jurisdiction of Russia. Crimea also is not a quasi-state used as leverage in Russian foreign policy. According to international law, Crimea remains a territory occupied by the Russian Federation, but in this case there are no peace talks and Russia claims that the peninsula is an integral part of its territory. That is why Russia's annexation of Crimea in March 2014 cannot be considered one of the protracted conflicts.

Russia is using local and regional contestation to maintain its influence in the EaP region. For example, supporting radical groups is among the strongest mechanisms of weakening social trust used by Russia in the EaP. In Ukraine - before the annexation of Crimea and the war in Donbas Russia had, for many years, been supporting radical groups such as football hooligans, Cossacks, irregular military groups, and far-right fighters (e.g., from The Other Russia, the Russian National Unity, the Eurasian Youth Union, and the newly-formed armed Cossacks) who served alongside the military during the conflict and were coordinated by the Russian secret services. ${ }^{10}$ Furthermore, Russia continues to strengthen separatist tendencies, for example by fostering Slavophile and Russophile organisations of the Rusyn minority in the Zakarpattia (Carpathian Ruthenia) region, the leader of whom, Petr Getsko, announced that Zakarpattia would follow the example of Donbas and declare secession from Ukraine. In addition, "activists calling themselves the Odessa Partisans make the claim that the city is Russian because $99 \%$ of its population 'speak and think' in Russian". ${ }^{11}$

One of the tools Russia used to restore its regional influence was a focus on undermining the societal resilience of the EaP countries. Taking into consideration that social trust is "a cooperative attitude towards other people based on the optimistic expectation that others are likely to respect one's own interests", ${ }^{12}$ Russia is interested in permanently weakening such trust in Ukraine, Georgia, and Moldova, which all have more or less realistic ambitions of joining the EU. The mechanism of the influence of Russia in these three countries is to use links between its own church and the Moscow Patriarchate of the Ukrainian Orthodox Church, the Georgian Orthodox Church, and the Russian Orthodox Church in

10 V. Likhachev, The far right in the conflict between Russia and Ukraine, Notes de l'Ifri Russie.Nei.Visions, no. 95, July 2016.

11 O. Lutsevych, Agents of the Russian world: proxy groups in the contested neighbourhood, "Research Paper", Chatham House The Royal Institute of International Affairs, Russia and Eurasia Programme, April 2016.

12 P. Coleman, Characteristics of Protracted, Intractable Conflict: Toward the Development of a Metaframework-I. Peace and Conflict, "Journal of Peace Psychology", vol. 9(1)/2003, DOI: https://doi.org/10.1207/S15327949PAC0901_01. 
Moldova. The Russian Orthodox Church has been helping to popularise the concept of the "Russian World" in the post-Soviet space, which is dangerous for social identity and statehood. ${ }^{13}$ In the interpretation of the Russian Orthodox Church, the notion of the "Russian World" covers areas that belonged to the mythical "Holy Rus". The leaders of the Russian Orthodox Church have long referred to the concept of the "Russian World" and the unity rhetoric of the "brotherly Slavic nations" to strengthen their influence in this region (this includes the Russian state, since the Russian Orthodox Church cooperates with and depends on the Russian government).

At the level of legitimacy, the most visible example of Russia's impact is also related to the orthodox churches in Ukraine, Georgia, and Moldova. ${ }^{14}$ To promote Russian interests, the Russian Church uses traditional Christian values and Orthodox identity, pastoral work, and the informal influence of its hierarchs. This suggests Russia's ability to shape public opinion, and its willingness to use the Orthodox Church to weaken Ukrainian legitimacy. However, the autocephaly of the Ukrainian Orthodox Church has been a blow to Russian soft power in Ukraine, all the more so because it was granted by the Ecumenical Patriarchate of Constantinople, which overruled over 300 years of Russian control over the Kyiv Metropolis and thus further limited Russia's cultural and socio-psychological impact on Ukrainian societal resilience. ${ }^{15} \mathrm{~A}$ similar situation is being explored in Georgia and Moldova. ${ }^{16}$

Another mechanism of undermining social resilience is Russian propaganda and disinformation. ${ }^{17}$ According to Kovalenko, Russian disinformation in Ukraine has been "used persistently as a tool to exacerbate

13 J. Chawryło, Patriarch Kirill's game over Ukraine, "OSW Commentary", no. $144 / 2014$.

${ }^{14}$ J. Gehman, L.M. Lefsrud, S. Fast, Social license to operate: Legitimacy by another name?, "Canadian Public Administration" 2017; A. Curanović, Russia's Mission in the World, "Problems of Post-Communism", vol. 4(66)/2019, DOI: https://doi.org/10 $.1080 / 10758216.2018 .1530940$.

${ }_{15}$ T. Olszański, The fight for canonical independence for Ukrainian Orthodoxy, "OSW Commentary", no. 272/2018.

16 L. Markozashvili, D. Dvalishvili, Russian smart power in Georgia, "Przegląd Politologiczny”, no. 4/2017, DOI: https://doi.org/10.14746/pp.2017.22.4.14.; K. Liik, M. Metodiev, N. Popescu, Defender of the faith? How Ukraine's Orthodox split threatens Russia, "Policy Brief ECFR" 2019; A. Curanović, The guardians of traditional values: Russia and the Russian Orthodox Church In the quest for status, "2014-15 Paper Series”, no. 1, Transatlantic Academy.

17 A. Legucka, Russia's long-term campaign of disinformation in Europe, "Carnegie Europe" 2020, https://carnegieeurope.eu/strategiceurope/81322 (access 15.11.2021). 
divisions in Ukrainian society and feed it with grievances, mistrust, and hatred... [it] prepared the ground for the full-fledged military invasion by the Kremlin in 2014". ${ }^{18} \mathrm{Kremlin}$ propaganda normalised violations of international law and human rights by undermining Ukrainian democratic institutions and eroding social values. The disinformation machine continues to reach the Ukrainian audience successfully by transforming propaganda narratives, using new modes of dissemination, and increasing the quality of fake news.

Ukrainian journalists once exposed a network of dozens of social media groups, including the Patriots of Ukraine, on multiple social media platforms, which were being coordinated from Moscow. These groups used pro-Ukraine symbolic and nationalistic rhetoric to undermine trust in the Ukrainian government and mobilise people for a "third Maidan". ${ }^{19}$ In 2018, Stop Fake, an organisation that regularly monitors pro-Kremlin narratives in Ukraine, discovered that 34 Ukrainian media outlets were sources of fake news, alongside a number of non-Russian "Ukrainian" media spreading fake news in Ukraine. ${ }^{20}$ According to Kovalenko, media outlets such as the Kharkiv News Agency pretend to be Ukrainian, in reality being a part of the St. Petersburg "Troll Factory". ${ }^{21}$ Since 2014, the Assembly of Young Journalists for Russianlanguage media has been organising annual forums financed by Russia. The aim is to "present an 'alternative view on Crimea' as a counter to the information block arising from the "Western hybrid war against the peninsula". ${ }^{22}$ During the COVID-19 pandemic, there has been a new wave of disinformation aimed at fuelling disorder and panic and strengthening the anti-vaccine movement. In April and May 2020 alone, the Institute of Mass Media found 66 stories on five websites (112.ua, newsone.ua, zik.ua, strana.ua, and unian. ua) containing information on secret laboratories in Ukraine. ${ }^{23}$

The information sphere is one where Russia leaves a long-term footprint by expanding its flawed standards of agenda setting, promoting favourable narratives, and undermining its viewers' ability to differentiate

18 O. Kovalenko, Ukrainian journalists at the forefront of countering Russian disinformation, "Euroasian State in Transition" 2019.

19 T.C. Helmus et al., Russian social media influence, "RAND Corporation" 2018, https://www.rand.org/content/dam/rand/pubs/research_reports/RR2200/RR2237/ RAND_RR2237.pdf (access 12.02.2020).

${ }^{20}$ O. Kovalenko, op.cit.

${ }^{21}$ Ibidem.

22 O. Lutsevych, Agents of the Russian world: proxy groups in the contested neighbourhood, "Chatham House Research Paper" 2016.

${ }_{23}$ S. Nazarenko, The Russian disinformation virus and its victims in Ukraine and the EU, Promote Ukraine, 2020, https://www.promoteukraine.org/the-russian-disinformation-virus-and-its-victims-in-ukraine-and-the-eu/ (access 23.09.2021). 
between truth and falsehood. Russian media broadcasters also produce the most traffic online. Both Russian outlets increasingly focus on young audiences by adapting content and form to make them smartphone-friendly. They also diversify types of messaging. It is also because the pro-Russian electorate has remained in the Donbas area.

\section{The Role of the EU in the Management of CO Risks}

The EU prefers stability in the EaP region, but unlike Russian involvement in the EaP, the European Union is reluctant to act openly (against Russia). For years, the EU has paid little attention to conflict resolution in its immediate neighbourhood, in part because some European countries feared Russia's reaction and accepted its special position as a guarantor of peace in the region. Since the annexation of Crimea in 2014, relations between the EU and the Russian Federation have been at an impasse and are based on the rule of selective engagement, when cooperation with Russia on issues which were in the EU's shared interests. There are still the five principles of EU policy towards Russia in power: 1) full implementation of the Minsk Agreements as a condition for lifting economic sanctions, 2) strengthening relations with the EU's eastern neighbours, 3) increasing the EU's resilience to Russian threats, 4) selective engagement on foreign policy issues, and 5) support for Russian civil society. However, it was - and still is - difficult to find those "shared interests". As contestation is fairly normal in contemporary political systems, political regimes have developed different mechanisms to deal with them.

The EaP has become an area of the EU's experience in the field of security, including observatory and monitoring missions. ${ }^{24}$ In September 2003, the EU was officially invited to participate in the negotiations concerning the Transnistrian conflict. Then, at the request of the presidents of Ukraine and Moldova in June 2005, the EU created the special training-and-control border assistance mission EUBAM, which was tasked with supporting the border and customs services of these countries. The goal of this mission was to combat smuggling, (illegal) trafficking, and customs fraud that occurs on the border, especially on its Transnistrian part, and to conduct training and support customs officers. The final declaration stated: 'the EU hopes that the mission will contribute to larger efforts to find a viable and sustainable solution to the Transnistria conflict'. The EU carried out the rule-of-law mission in Georgia, EUJUST Themis, at the request of the Georgian government. In August 2008, Georgia and

${ }^{24}$ A. Legucka, A. Legieć, Protracted Conflicts in the EU's Neighbourhood: Does Resilience Apply? „EU-LISTCO Policy Paper”, no. 6, June 2020. 
Russia fought a five-day war over South Ossetia, Moscow recognised Abkhazia and South Ossetia as being independent, the United Nations mission left Abkhazia, and the Organisation for Security and Cooperation in Europe (OSCE) withdrew from South Ossetia because of Russia's veto of such missions. ${ }^{25}$ Since then, the only international forum involved in these conflicts has been the four-times-yearly Geneva International Discussions, during which the parties meet but without formal labels and in which political and status issues are not properly debated. They discuss security-related issues and humanitarian needs of the conflict-affected population and focus on improving the situation of the conflict-affected population. The EU launched the EU Monitoring Mission (EUMM) and, since 2009, it has become the only international monitoring presence in Georgia. This civilian mission is tasked with monitoring the compliance of the parties with the ceasefire agreement and its implementation measures and with contributing to stability, normalisation, and confidence building by facilitating communication between parties on the ground. The EU has contributed - through civilian and military operations - to the monitoring of peace agreements and assistance in their implementation beyond EUMM Georgia. ${ }^{26}$ The EU has spent more than $€ 1$ billion in aid to eastern Ukraine since 2014. ${ }^{27}$ The EU has established a European Advisory Mission (EUAM) in Ukraine, which has a strategic brief, advising on long-term policy reform. ${ }^{28}$

To sum up, the intensity of the European Union's engagement in the countries of the common neighbourhood has weakened compared to the 1990 s and the first decade of the 21 st century. An evolution of the means and methods used by the EU in its policy towards the discussed countries can also be observed. Currently, the European Union focuses on economic, social, and expert support. It is much less focused on openly challenging the order in the region, including the position of the Russian Federation. This is conditioned by several challenges faced by the EU, the lack of a common position on the issue of the EaP countries and Russia itself within the Member States, as well as the strengthening of Moscow's assertiveness. Concerning the Nagorno-Karabakh and Donbas conflicts, the EU adopted the role of an observer rather than an active player. It can be argued that some of the EaP countries, Azerbaijan, and Ukraine,

25 Ibidem.

$26 \mathrm{http} / /$ eeas.europa.eu/archives/docs/csdp/structures-instruments-agencies/ european-security-defencecollege/pdf/handbook/final_handbook_on_csdp_missions_and_operations.pdf (access 1.11.2021).

${ }_{27}$ https://ec.europa.eu/echo/where/europe/ukraine_en (access 1.11.2021).

${ }_{28}$ T. de Waal, N. von Twickel, op.cit. 
are the ones challenging Russia's order and its dominance in the region. Azerbaijan, by unfreezing the Nagorno-Karabakh conflict and regaining part of its territory, and Ukraine, by a significant pro-Western turn in its policy. EU activity, focused on strengthening the resilience of EaP states and societies in this context can reinforce this trend.

\section{Conclusions}

Contested orders often involve a configuration of actors, in which some challenge the legitimacy of the "rules of the game" and the legitimacy of political institutions. The EU and the Russian Federation compete in the political, economic, and cultural domains. While democratic polities rely on institutionalised deliberation, majority decisions, and accountability, non-democratic systems use cooptation and repression. Russia has different aims and tools regarding foreign policy when it comes to the EaP. Russia is trying to protect its sphere of influence, block the enlargement of the EU and NATO, and halt the spread of the liberal model, which is seen as a challenge to its political elite. While the current goal of EU involvement in the EaP states remains to strength societal resilience, it is in Russia's interest to weaken it. For this purpose, it uses local or regional contestation (being social, political, or military). Both actors have different goals, but also different instruments resulting from their nature - state vs. international organisation. The greater intensity of Russia's involvement in the EaP states results, among other things, from the vitality of its interests in the area, a structural unity facilitating decisionmaking and implementation, a better knowledge of the countries of the common neighbourhood, and something akin to "being on the spot". Another significant advantage is a centralised information policy controlled by the Russian government. The EU, which does not have these advantages and, at the same time, treats Russia as an important partner (mainly economically and also as a supplier of raw materials), relies on other, long-term actions not aimed directly at Russia.

\section{References}

Börzel T.A., Hüllen V., One voice, one message, but conflicting goals: cohesiveness and consistency in the European Neighbourhood Policy, "Journal of European Public Policy”, no. 7(21)/2014, DOI: https://doi.org/10.10 80/13501763.2014.912147.

Börzel T.A., Risse T., Conceptual framework: fostering resilience in areas of limited statehood and contested orders, "EU-LISTCO Working Paper", no. 1/2018, DOI: https://doi.org/10.1093/oxfordhb/9780198797203.013.1. 
Chawryło J., Patriarch Kirill's game over Ukraine, "OSW Commentary", no. 144/2014.

Coleman P., Characteristics of Protracted, Intractable Conflict: Toward the Development of a Metaframework-I. Peace and Conflict, "Journal of Peace Psychology", vol. 9(1)/2003, DOI: https://doi.org/10.1207/ S15327949PAC0901_01.

Curanović A., Russia's Mission in the World, "Problems of PostCommunism", vol. 4(66)/2019, DOI: https://doi.org/10.1080/1075821 6.2018.1530940.

Curanović A., The guardians of traditional values: Russia and the Russian Orthodox Church In the quest for status, "2014-15 Paper Series", no. 1/2015, Transatlantic Academy, Washington 2015.

Draude A., Hölck L., Stolle D., Social trust, in: The Oxford Handbook of Governance and Limited Statehood, eds. A. Draude, T. A. Börzel, T. Risse, Oxford 2018, DOI: https://doi.org/10.1093/oxfordhb/978019 8797203.001.0001.

Gehman J., Lefsrud L.M., Fast S., Social license to operate: Legitimacy by another name?, "Canadian Public Administration", vol. 60(2)/2017, DOI: https://doi.org/10.1111/capa.12218.

Helmus T.C. et al., Russian social media influence, "RAND Corporation" 2018, https://www.rand.org/content/dam/rand/pubs/research_reports/ RR2200/RR2237/RAND_RR2237.pdf (access 12.02.2020).

http://eeas.europa.eu/archives/docs/csdp/structures-instrumentsagencies/european-security-defencecollege/pdf/handbook/final_ handbook_on_csdp_missions_and_operations.pdf (access 1.11.2021). https://ec.europa.eu/echo/where/europe/ukraine_en (access 1.11.2021).

Kovalenko O., Ukrainian journalists at the forefront of countering Russian disinformation, "Euroasian State in Transition" 2019.

Legucka A., Frozen and Freezing Conflicts in Eastern Europe and South Caucasus: Implications for Regional Security, "Yearbook of the Institute of East-Central Europe", vol. 2(15)/2017.

Legucka A., Legieć A., Protracted Conflicts in the EU's Neighbourhood: Does Resilience Apply? „EU-LISTCO Policy Paper”, no. 6, June 2020.

Legucka A., Operacja pokojowa Rosji w Górskim Karabachu-cele i wyzwania, „Biuletyn PISM”, no. 17(2215), 29.01.2021.

Legucka A., Russia'slong-term campaign of disinformation in Europe, "Carnegie Europe” 2020, https://carnegieeurope.eu/strategiceurope/81322 (access 15.11.2021).

Liik K., Metodiev M., Popescu N., Defender of the faith? How Ukraine's Orthodox split threatens Russia, "Policy Brief ECFR" 2019. 
Likhachev V., The far right in the conflict between Russia and Ukraine, Notes de l'Ifri Russie.Nei.Visions, no. 95, July 2016,

Lutsevych O., Agents of the Russian world: proxy groups in the contested neighbourhood, "Research Paper", Chatham House The Royal Institute of International Affairs, Russia and Eurasia Programme, April 2016.

Markozashvili L., Dvalishvili D., Russian smart power in Georgia, "Przegląd Politologiczny", no. 4/2017, DOI: https://doi.org/10.14746/ pp.2017.22.4.14.

Nazarenko S., The Russian disinformation virus and its victims in Ukraine and the EU, Promote Ukraine', 2020, https://www.promoteukraine.org/therussian-disinformation-virus-and-its-victims-in-ukraine-and-the-eu/ (access 23.09.2021).

Olszański T., The fight for canonical independence for Ukrainian Orthodoxy, "OSW Commentary", no. 272/2018.

Racz A., The frozen conflicts of the EU's Eastern neighbourhood and their impact on the respect of human rights, European Parliament, DirectorateGeneral for External Policies, http://www.europarl.europa.eu/RegData/ etudes/STUD/2016/578001/EXPO_STU(2016) 578001_EN.pdf (access 12.10.2021).

Waal T. de, von Twickel N., Beyond Frozen Conflict Scenarios for the Separatist Disputes of Eastern Europe, CEPS, Brussels 2020.

Włodkowska-Bagan A., Rywalizacja międzynarodowa na obszarze poradzieckim, Warszawa 2013. 